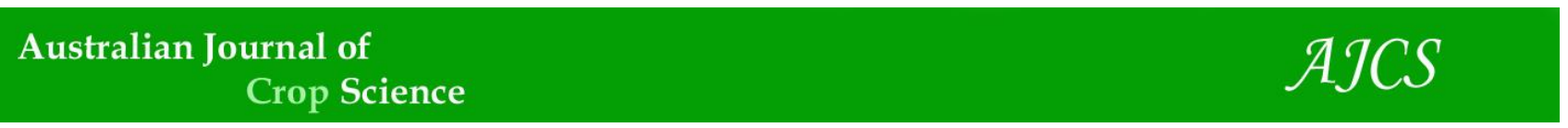

AJCS 14(08):1348-1354 (2020)

ISSN:1835-2707

doi: 10.21475/ajcs.20.14.08.p2648

\title{
Growth analysis of tomato for industrial processing as a function of nitrogen doses
}

\author{
Leonardo Correia Costa', Arthur Bernardes Cecílio Filho' ${ }^{1 *}$, Rodolfo Gustavo Teixeira Ribas ${ }^{2}$, Alexson \\ Filgueiras Dutra', Antonio Márcio Souza Rocha', José Carlos Barbosa'
}

\author{
'São Paulo State University - Unesp, 14884-900, Jaboticabal, SP, Brazil \\ ${ }^{2}$ Federal Institute of Education, Science and Technology of Rondônia (IFRO), Campus Cacoal, Rondônia, \\ Brazil
}

\section{*Corresponding author: arthur.cecilio@unesp.br}

\section{Abstract}

Nitrogen $(\mathrm{N})$ is considered to be the nutrient that most affects plant growth. Understanding this mechanism helps in crop management and planning. This study analyzes the growth of tomato plants (Heinz 9553) for industrial purposes as a function of $\mathrm{N}$ doses $\left(0,60,120\right.$ and $\left.180 \mathrm{~kg} \mathrm{ha}^{-1}\right)$. The experiment was carried out from April to August 2015, in Barretos, São Paulo State, Brazil. The experimental design was a randomized blocks, in plots subdivided in time, with three replicates. Growth assays were performed at $14,28,42,56,70,84,96,112$ and 126 days after transplanting (DAT). Fertilization with $180 \mathrm{~kg}^{-1} \mathrm{~N}$ provided greater leaf area, leaf dry mass, shoot dry mass (leaves + stems), fruit dry mass, total dry mass, leaf area index, leaf area ratio and leaf mass ratio at the end of the cycle. The lowest relative growth rate and specific leaf area were verified with $180 \mathrm{~kg} \mathrm{ha}^{-1}$. For all $\mathrm{N}$ doses, the absolute growth rate was small up to 56 DAT and, subsequently, $\mathrm{N}$ doses promoted distinct increases in the index.

Keywords: Solanum lycopersicum; nitrogen fertilization; growth analysis.

Abbreviations: AAR_apparent assimilation rate; Al_aluminum; B_boron; Ca_calcium; CEC_cations exchange capacity; $\mathrm{Cu}$ _cooper; DAT_days after transplanting; FDM_fruit dry mass; Fe_iron; $H_{-}$hydrogen; K_potassium; LA_leaf area; LAI_leaf area index; LAR_leaf

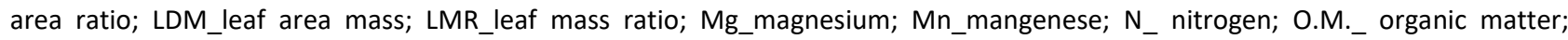
P_phosphurus; RGR_relative growth rate; RPTN_relative power of total neutralization; S_sulfur; SB_sum of bases; SDM_shoot dry mass; SLA_specific leaf area; TDM_total dry mass; Zn_zinc.

\section{Introduction}

There are many production factors that interact and affect crop growth and development. Among them is fertilization, a technique that when properly managed, contributes to the maximum yield potential of crops. Among the nutrients, nitrogen $(N)$ is the second most demanded by tomato (Lucena et al., 2013). This nutrient participates in several metabolic processes in plants, such as photosynthesis, protein and nucleic acid synthesis (Lawlor, 2002), control of phytohormones, cell division and stretching (Rashid et al., 2016). Proper use of nitrogen fertilizers promotes a higher growth of the vegetative organs of the plant in early cultivation, contributing to the increase of the photosynthetic canopy, which is determinant for the crop to express its maximum yield potential (San Martín-Hernández et al., 2016). Nitrogen fertilization should be well-managed to minimize losses by leaching, volatilization, and to avoid $\mathrm{N}$ deficiency. When $\mathrm{N}$ fertilization is insufficient, it can promote early flowering and fruit maturation (Kumar et al., 2013), in addition to lower biomass production of both vegetative and reproductive parts (Almanza-Merchán et al., 2016). Excessive $N$ doses raise the production cost and the risk of polluting springs and atmospheric air (Kanter et al., 2015). Excessive nitrogen fertilization may also delay flowering and fruit maturation (Kumar et al., 2013), increase biomass production of vegetative organs and decrease the biomass of reproductive organs of plants (Wira et al., 2013).
The $\mathrm{N}$ dose can alter the plant biomass partition between vegetative and reproductive parts, and with this, growth analysis allows to verify the effect of agronomic practices, among them fertilization. This technique is inexpensive and is a very useful tool to aid rational crop planning (AlmanzaMerchán et al., 2016). In the region of Guaíra, one of the most important Brazilian regions in terms of tomato production for processing, farmers fertilize the crop without scientific criteria with up to $50 \%$ more than the recommended $\mathrm{N}$ dose according to Trani and Raij (1997). Unfortunately, despite the importance of tomatoes for processing, often their technical information for crop management is brought from tomato crop aiming at the fresh fruit production. No studies were found on this subject for tomatoes for industrial processing. In this context, we performed the growth analysis of 'Heinz 9553' tomato to characterize the effect of $\mathrm{N}$ doses on its growth and yield; and thus, obtain specific information for this crop to improve the crop management.

Results and Discussion

\section{Tomato growth}

For LA, LDM and SDM, there was adjustment to the multiple polynomial regression model. Plant responses to both 
factors ( $\mathrm{N}$ and evaluation times) regarding these three traits were similar. The highest LA $\left(8,483 \mathrm{~cm}^{2}\right.$ plant $\left.{ }^{-1}\right), \operatorname{LDM}(47 \mathrm{~g}$ plant $^{-1}$ ) and SDM (111 g plant $^{-1}$ ) were obtained at 126 DAT with $180 \mathrm{~kg} \mathrm{ha}^{-1} \mathrm{~N}$ (Figure 1).

The means observed for FDM and TDM also fitted the multiple polynomial regression model. The highest FDM was observed with $180 \mathrm{~kg} \mathrm{ha}^{-1} \mathrm{~N}$ at 126 DAT, of $214 \mathrm{~g} \mathrm{plant}^{-1}$, and the highest TDM ( $325 \mathrm{~g} \mathrm{plant}^{-1}$ ) was obtained at the same rate and time (Figure 1 ).

Regarding the LDM, SDM and LDM/SDM values for doses 0 and $180 \mathrm{~kg} \mathrm{ha}^{-1} \mathrm{~N}$, in 28-day periods, the plants fertilized with $180 \mathrm{~kg} \mathrm{ha}^{-1} \mathrm{~N}$ presented a higher proportion of leaves than unfertilized plants $\left(0 \mathrm{~kg} \mathrm{ha}^{-1} \mathrm{~N}\right)$ (Table 1$)$.

Near the flowering period, which started at 42 DAT, even with the highest $\mathrm{N}$ doses, small increases were observed in the growth of vegetative parts. At early vegetative growth, the plant is composed mainly of leaves, whose photoassimilate production is destined to the formation of new vegetative organs that will later be responsible for meeting the demand for new vegetative and reproductive organs (Omaña and Peña, 2015).

From 56 DAT, the effect of $\mathrm{N}$ doses on LA, LDM and SDM were more pronounced, where the higher $\mathrm{N}$ rate, caused higher observed values. The largest increases in these traits were occurred between 42 and 98 DAT (Figure 1). At fruit maturation, which occurred in the last 30 days of the cycle (hence, from $98 \mathrm{DAT}$ ), there was a slowdown in the growth of $L A$ and in the mass accumulation in leaves and stems.

The lower increase of LA, LDM and SDM in the final stage of the cycle varied as function of $\mathrm{N}$ doses. Similar response to nitrogen fertilization was observed for SDM, with increases of $4 \%$ and $12 \%$ for the doses of 0 and $180 \mathrm{~kg} \mathrm{ha}^{-1}$, respectively. $\mathrm{A}$ higher $\mathrm{N}$ rate increases the number of leaves (Pietro-Souza et al., 2013), which results in higher LA, LDM and SDM, as verified in this work.

At 126 DAT, with $180 \mathrm{~kg} \mathrm{ha}^{-1} \mathrm{~N}, \mathrm{LA}, \mathrm{LDM}$ and SDM were $62 \%$, $68 \%$ and $32 \%$ higher, respectively, compared to control plants that were not fertilized with $\mathrm{N}$, agreeing with the results of Wira et al. (2013). Analyzing the LDM/SDM ratio, showed that the proportion of LDM in total SDM was increased throughout the cycle as the $\mathrm{N}$ rate increased (Table 1). The maintenance of the photosynthetically active area is related to obtaining high yield, which depends on the $\mathrm{N}$ rate provided for the crop.

Therefore, under insufficient $\mathrm{N}$ doses, there was redistribution of $\mathrm{N}$ from the older leaves to younger parts of the plant, such as leaves and stems, and later to fruits, which led to early senescence of the photosynthetic apparatus and reduced proportion of LDM in SDM (leaves and stems) (Tei et al., 2002, Elia and Conversa, 2012). Thus, the deceleration of LA growth and LDM accumulation was more pronounced at doses 0 and $60 \mathrm{~kg} \mathrm{ha}^{-1} \mathrm{~N}$. Moreover, a trend of decrease of LA and LDM was observed from 98 DAT, which was not verified in the fertilization with 120 and $180 \mathrm{~kg} \mathrm{ha}^{-1} \mathrm{~N}$ (Figure 1). For SDM, regardless of $\mathrm{N}$ rate, the trend of decrease was not verified until the end of the cycle, a fact that confirms that there was only loss of leaves, not stems.

Up to 98 DAT, plants accumulated $71 \%, 69 \%, 68 \%$ and $67 \%$ of the FDM production at doses $0,60,120$ and $180 \mathrm{~kg} \mathrm{ha}^{-1} \mathrm{~N}$, respectively. However, although the percentages of the total accumulated are similar, the maximum amounts of FDM were obtained at the highest $\mathrm{N}$ doses, as 144, 132, 122 and $114 \mathrm{~g} \mathrm{plant}^{-1}$, with $180,120,60$ and $0 \mathrm{~kg} \mathrm{ha}^{-1} \mathrm{~N}$, respectively. The result is explained by the increase of LA, LDM, SDM and LAl for each $\mathrm{N}$ rate (Figures 1 and 2). Most of the FDM comes from the photoassimilates produced in the leaves and transported to the fruits, which depends on the source-drain relationship (Almanza-Merchán et al., 2016). Between 56 and 112 DAT, FDM was increased from 138 to 150, 164 and $180 \mathrm{~g} \mathrm{plant}^{-1}$ at doses $0,60,120$ and $180 \mathrm{~kg} \mathrm{ha}^{-1} \mathrm{~N}$, respectively (Figure 1 ). This period of high FDM increase, which included the initial growth and fruit filling periods, coincided with the highest demand of $\mathrm{N}$ by tomato (Wira et al., 2013). In the fruiting period, fruits become the main drain of photoassimilates and nutrients in the plant, which reduced the increase of vegetative material (San-MartínHernández et al., 2016). This reduction motivated the smaller increases in LA, FDM, SDM and LAI (Figures 1 and 2). The values verified for growth traits (LA, LDM and SDM and LAI) can be considered adequate for 'Heinz 9553' tomato, since the maximum fruit fresh mass, obtained with $180 \mathrm{~kg}$ $\mathrm{ha}^{-1} \mathrm{~N}$, corresponded to $4.3 \mathrm{~kg}$ plant ${ }^{-1}$ and yield of $143 \mathrm{t} \mathrm{ha}^{-1}$, considering fruits with $5 \%$ dry mass. The fruit yield estimated in the present study can be considered high, since it was $40 \%$ higher than the average yield, of $102.5 \mathrm{t} \mathrm{ha}^{-1}$ ( 90 $\left.115 \mathrm{t} \mathrm{ha}^{-1}\right)$, obtained by tomato producers in the region of Guaíra, SP (Cecílio Filho and Nowaki, 2016).

TDM increased up to 126 DAT regardless of $\mathrm{N}$ rate. However, with the fertilization of $180 \mathrm{~kg} \mathrm{ha}^{-1} \mathrm{~N}$, the TDM was $25 \%$ higher than that observed in plants that did not receive nitrogen fertilization. Similar to the work done by Omaña and Peña (2015) with tomato, the highest values of FDM and TDM was occurred in plants with greater accumulation and continuous production of SDM.

The TDM accumulation for $\mathrm{N}$ doses up to 70 DAT ranged from $37 \%$ to $39 \%$, indicating that more than $60 \%$ of the TDM was accumulated from 70 DAT until the end of the cycle, during which period fruit production is intensified. At the end of the cycle, we found that $61 \%, 62 \%, 63 \%$ and $66 \%$ of the TDM production corresponded to FDM when $0,60,120$ and $180 \mathrm{~kg} \mathrm{ha}^{-1} \mathrm{~N}$ were applied, respectively.

\section{Growth analysis indexes}

AAR did not fit the linear, quadratic, and multiple polynomial regression model. The means of the RGR, LAR, SLA, LMR and LAl indices were adjusted to the multiple polynomial regression model as a function of $\mathrm{N}$ rate and evaluation time. AAR did not show a response pattern, either within or between doses. The highest AARs were observed at 70 DAT, with 0 and $120 \mathrm{~kg} \mathrm{ha}^{-1} \mathrm{~N}$; and at $84 \mathrm{DAT}$, with 60 and $180 \mathrm{~kg}$ $\mathrm{ha}^{-1} \mathrm{~N}$ (Table 2).

The variables RGR, LAR, SLA and LMR were higher at early cultivation (14 DAT), and gradually decreased up to 126 DAT for RGR, LAR and LMR; and up to 109 DAT for SLA, when there were small increases up to 126 DAT of tomato (Figure 2). From $98 \mathrm{DAT}$, the RGRs became smaller with $180 \mathrm{~kg} \mathrm{ha}^{-1}$ $\mathrm{N}$ than with 0,60 and $120 \mathrm{~kg} \mathrm{ha}^{-1} \mathrm{~N}$. From 70 DAT to 126 DAT, the LAR with $180 \mathrm{~kg} \mathrm{ha}^{-1} \mathrm{~N}$ fertilization was higher than the LAR verified with $0 \mathrm{~kg} \mathrm{ha}^{-1} \mathrm{~N}$. With fertilization of $180 \mathrm{~kg}$ $\mathrm{ha}^{-1} \mathrm{~N}$, the SLAs were smaller than those observed at lower $\mathrm{N}$ doses, from 14 DAT to 126 DAT. From 70, 84 and 98 DAT up to 126 DAT, with fertilization of $180 \mathrm{~kg} \mathrm{ha}^{-1} \mathrm{~N}$, the LMR was higher than that observed at 0,60 and $120 \mathrm{~kg} \mathrm{ha}^{-1} \mathrm{~N}$, respectively.

LAl was increased throughout the cycle, with the highest LAI was observed at $126 \mathrm{DAT}$, at $180 \mathrm{~kg} \mathrm{ha}^{-1} \mathrm{~N}$. However, LAI showed a stabilization tendency at doses 0 and $60 \mathrm{~kg} \mathrm{~h}^{-1} \mathrm{~N}$ from 112 DAT (Figure 2). 
Table 1. Growth values of 'Heinz 9553 ' tomato at doses 0 and $180 \mathrm{~kg} \mathrm{ha}^{-1}$ of $\mathrm{N}$, in periods of 28 days, from 14 days after transplanting to harvesting.

\begin{tabular}{|c|c|c|c|c|c|c|}
\hline \multirow{2}{*}{ Period } & \multicolumn{3}{|c|}{$0 \mathrm{~kg} \mathrm{ha}^{-1} \mathrm{~N}$} & \multicolumn{3}{|c|}{$180 \mathrm{~kg} \mathrm{ha}^{-1} \mathrm{~N}$} \\
\hline & LDM & SDM & LDM/SDM & LDM & SDM & LDM/SDM \\
\hline & \multicolumn{2}{|c|}{----- g plant $^{-1}$} & - & \multicolumn{2}{|c|}{------ g plant $^{-1}$----- } & - \\
\hline $14-42$ & 8 & 11 & 0.73 & 10 & 24 & 0.42 \\
\hline $28-56$ & 14 & 33 & 0.42 & 18 & 38 & 0.47 \\
\hline $42-70$ & 10 & 28 & 0.36 & 16 & 34 & 0.47 \\
\hline $56-84$ & 8 & 24 & 0.33 & 13 & 30 & 0.43 \\
\hline $70-98$ & 6 & 20 & 0.30 & 11 & 26 & 0.42 \\
\hline $84-112$ & 3 & 16 & 0.19 & 8 & 22 & 0.36 \\
\hline $98-126$ & 1 & 12 & 0.08 & 5 & 18 & 0.28 \\
\hline
\end{tabular}

LDM = leaf dry mass; SDM = shoot dry mass; LDM/SDM = Relationship between the two characteristics.
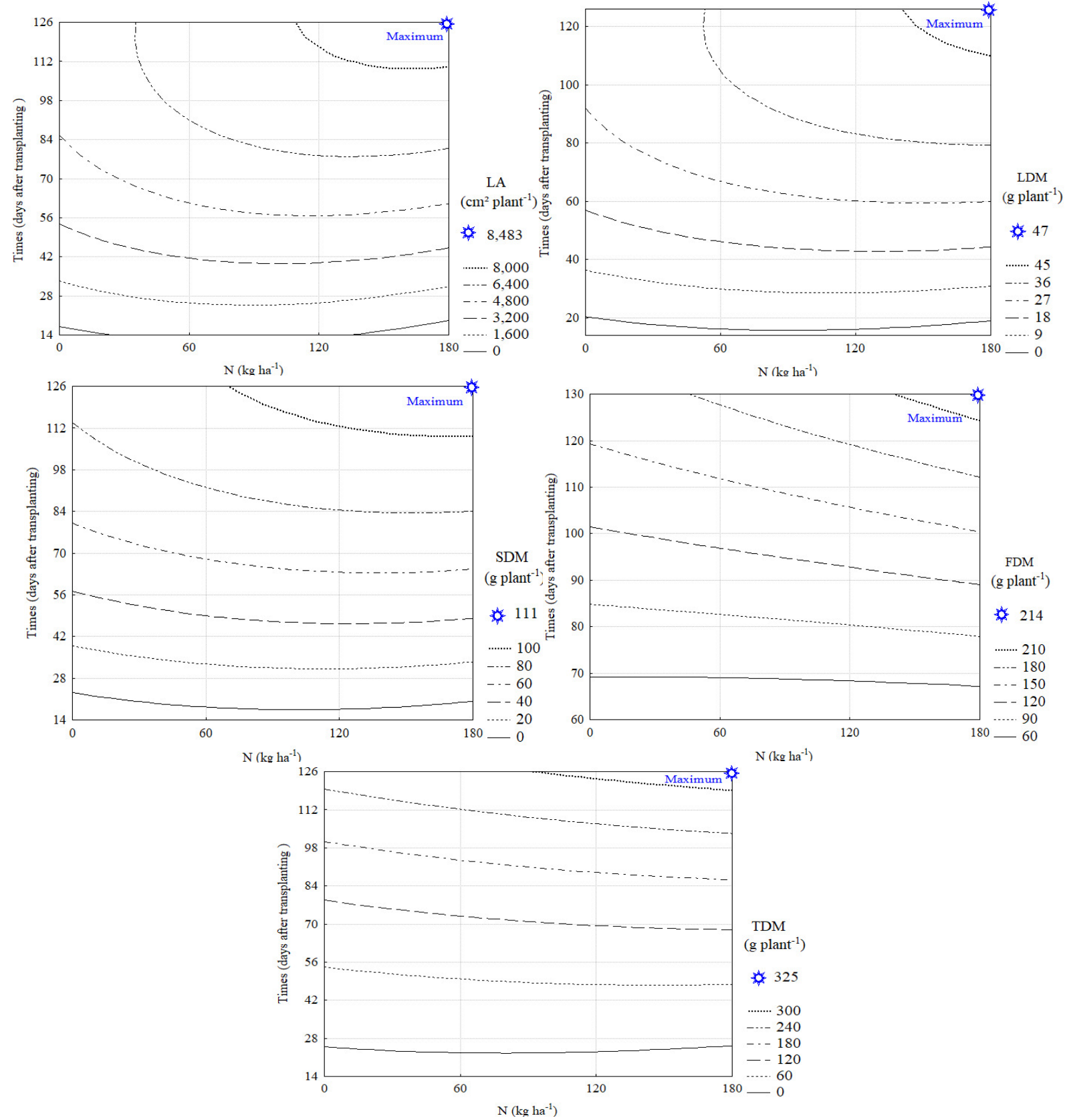

$y L A=-1,982.8224+13.7758 x+125.7818 y-0.1032 x^{2}-0.5435 y^{2}+0.1812 x y\left(R^{2}=0.85 ; F=36.73^{* *}\right)$

$y L D M=-13.93+0.0502 x+0.7506 y-0.0004 x^{2}-0.0033 y^{2}+0.001 x y\left(R^{2}=0.83 ; F=29.44^{* *}\right)$

YSDM $=-33.7775+0.1329 x+1.581 y-0.0007 * x^{2}-0.0051 y^{2}+0.0011 x y\left(R^{2}=0.87 ; F=39.32 * *\right)$

$y F D M=-93.8753-0.3306 x+2.4718 y+0.0002 x^{2}-0.0036 y^{2}+0.0047 x y\left(R^{2}=0.78 ; F=10.17^{* *}\right)$

$y T D M=-40.9371+0.021 x+1.4569 y-0.0007 x^{2}+0.0074 y^{2}+0.0037 x y\left(R^{2}=0.90 ; F=56.50^{* *}\right)$

Fig 1. Leaf area (LA), leaf dry mass (LDM), shoot dry mass (SDM), fruit dry mass and total dry mass (TDM) of the 'Heinz 9553' tomato as function of $\mathrm{N}$ doses and evaluation times. 


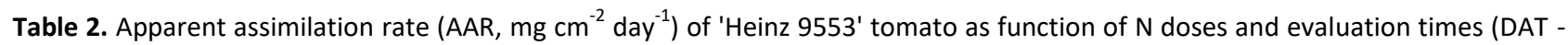
days after transplanting).

\begin{tabular}{|c|c|c|c|c|}
\hline \multirow[t]{2}{*}{ Evaluation times } & \multicolumn{3}{|c|}{$\mathrm{N}$ doses $\left(\mathrm{kg} \mathrm{ha}^{-1}\right)$} & \multirow[b]{2}{*}{180} \\
\hline & 0 & 60 & 120 & \\
\hline 14 & 0.5 & 0.5 & 0.6 & 0.5 \\
\hline 28 & 0.9 & 1.1 & 0.9 & 1.3 \\
\hline 42 & 0.6 & 0.5 & 0.7 & 0.6 \\
\hline 56 & 0.3 & 0.5 & 0.5 & 0.6 \\
\hline 70 & 1.5 & 0.9 & 1.1 & 0.5 \\
\hline 84 & 0.0 & 1.2 & 0.6 & 1.7 \\
\hline 98 & 1.2 & 0.0 & 0.5 & 0.0 \\
\hline 112 & 0.4 & 1.2 & 0.0 & 0.9 \\
\hline 126 & 0.4 & 0.5 & 0.8 & 0.0 \\
\hline
\end{tabular}

Table 3. Growth values of 'Heinz 9553' tomato corresponding to the dose of $180 \mathrm{~kg} \mathrm{ha}^{-1} \mathrm{~N}$ from 42 to 112 days after transplanting (DAT).

\begin{tabular}{|c|c|c|c|c|c|c|}
\hline \multirow{2}{*}{$\begin{array}{l}\text { Indexes and } \\
\text { characteristics }\end{array}$} & \multicolumn{6}{|c|}{ Days after transplanting } \\
\hline & 42 & 56 & 70 & 84 & 98 & 112 \\
\hline LA $\left(\mathrm{cm}^{2}\right.$ plant $\left.^{-1}\right)$ & 2847 & 4320 & 5578 & 6623 & 7456 & 8076 \\
\hline LDM (g plant ${ }^{-1}$ ) & 15.4 & 23.9 & 31.1 & 37.0 & 41.7 & 45.0 \\
\hline SDM (g plant ${ }^{-1}$ ) & 33.2 & 51.1 & 67.0 & 80.9 & 92.8 & 102.7 \\
\hline FDM (g plant ${ }^{-1}$ ) & 0.0 & 27.6 & 67.7 & 106.4 & 143.7 & 179.5 \\
\hline$R G R\left(g^{-1}\right.$ day $\left.^{-1}\right)$ & 0.10 & 0.08 & 0.06 & 0.05 & 0.03 & 0.02 \\
\hline $\operatorname{LAR}\left(\mathrm{cm}^{2} \mathrm{~g}^{-1}\right)$ & 124.0 & 94.9 & 70.7 & 51.4 & 36.9 & 27.2 \\
\hline $\operatorname{SLA}\left(\mathrm{cm}^{2} \mathrm{~g}^{-1}\right)$ & 221.4 & 203.7 & 190.4 & 181.4 & 176.9 & 176.7 \\
\hline $\operatorname{LMR}\left(\mathrm{g} \mathrm{g}^{-1}\right)$ & 0.5 & 0.4 & 0.3 & 0.3 & 0.2 & 0.2 \\
\hline LAI $\left(\mathrm{m}^{2} \mathrm{~m}^{-2}\right)$ & 1.0 & 1.5 & 1.9 & 2.3 & 2.5 & 2.7 \\
\hline
\end{tabular}

The AAR showed increase for all $\mathrm{N}$ doses up to 28 DAT (Table 2). At this stage, most of the leaves are exposed to solar energy, where there was no practical shading, and the LA was proportionally smaller than the dry mass, increasing the photosynthetic efficiency of plants. The AAR decreased between 28 and 56 DAT, indicating that the LA in this period was proportionally higher than the TDM (leaves + stems) produced, and/or that the leaves began to overlap, reducing the photosynthetic efficiency.

The highest AARs were observed at 70 DAT, with 0 and 120 $\mathrm{kg} \mathrm{ha}^{-1} \mathrm{~N}$; and at $84 \mathrm{DAT}$, with 60 and $180 \mathrm{~kg} \mathrm{ha}^{-1} \mathrm{~N}$, indicating that at these periods and doses, the LA was proportionally lower than the TDM (leaves, stem and fruits) produced, increasing the photosynthetic efficiency, probably by the expressive contribution of FDM to TDM.

The higher RGR in the initial stage (Figure 2) was occurred due to higher cell division, in addition to the plant having more meristems and growing leaves (Azofeifa and Moreira, 2004). The decrease of RGR throughout the cycle was occurred due to the continuous accumulation of TDM and the reduction of the relative capacity of the plant to grow throughout the cycle (Ardila et al., 2011). The decrease in RGR was more pronounced from 42 DAT up to 98 DAT (Figure 2), a period in which the production of stems and leaves was high, also comprising the beginning of fruit growth. This led to increasing the TDM difference between the evaluated periods. From 98 DAT, the increase in FDM continued to occur, but the increases in LA, LDM and SDM became smaller, decreasing the difference between the TDM of the analyzed periods, resulting in the slowdown of the RGR.

From 98 DAT, RGRs were lower in the fertilization with 180 $\mathrm{kg} \mathrm{ha}^{-1} \mathrm{~N}$ than those verified at doses 0,60 and $120 \mathrm{~kg} \mathrm{ha}^{-1}$ $\mathrm{N}$, indicating that in the fertilization with $180 \mathrm{~kg} \mathrm{ha}^{-1} \mathrm{~N}$, the plant capacity to emit or maintain vegetative organs (mainly leaves) was higher, even in the most advanced evaluation periods of the crop cycle. This can be verified by the LDM/SDM ratio, which at 98 and 126 DAT was 0.08 and 0.28 , with 0 and $180 \mathrm{~kg} \mathrm{ha}^{-1} \mathrm{~N}$, respectively (Table 1).

LAR reduction was more pronounced up to 56 DAT, since the plant had proportionally higher LA per TDM unit (Figures 1 and 2). In this period, the increase in leaf production is proportionally higher than the increase in TDM. From 56 DAT, LAR reduction was less pronounced, possibly due to the decrease in the difference between LA and TDM, since this index represents the LA size per TDM unit throughout the cycle (Benincasa, 2003). At 126 DAT, the LAR at the dose of $180 \mathrm{~kg} \mathrm{ha}^{-1} \mathrm{~N}$ was $69 \%, 16 \%$ and $4 \%$ higher than the LAR verified at 0,60 and $120 \mathrm{~kg} \mathrm{ha}^{-1} \mathrm{~N}$, respectively (Figure 2). This indicates that in fertilization with $180 \mathrm{~kg} \mathrm{ha}^{-1} \mathrm{~N}$, leaf emission and/or leaf maintenance was higher, contributing more significantly to the maintenance of LA until the end of the crop cycle.

Throughout the tomato crop cycle, the SLA was lower with $180 \mathrm{~kg} \mathrm{ha}^{-1} \mathrm{~N}$, and reached its minimum at 109 DAT, when it was $7 \%$ lower than the SLA of plants not fertilized with nitrogen (Figure 2). Thereafter, up to $126 \mathrm{DAT}$, there was a small increase in SLA and a continuous increase in LA and LDM (Figures 1, 2). Notwithstanding, the increase in LDM was not proportional to the increase in LA, indicating that in this period, the transport of photoassimilates produced in the leaves to the fruits is more accentuated (Figure 1) (Dartora et al., 2014).

The highest LMRs was occurred in the initial growth periods due to higher leaf production. Throughout the cycle, there was a gradual decrease of LMR, indicating the reduction of LDM increase and reduced size of the photosynthetic apparatus with plant aging. At 126 DAT, the LMR with $180 \mathrm{~kg}$ ha $^{-1} \mathrm{~N}$ was $100 \%, 50 \%$ and $20 \%$ higher than that observed with 0,60 and $120 \mathrm{~kg} \mathrm{ha}^{-1} \mathrm{~N}$, respectively (Figure 2). Such 
fact characterizes that the increase of LDM up to the end of the crop cycle is higher with higher $\mathrm{N}$ doses. When the $\mathrm{N}$ supply in the tomato is reduced, the distribution of photoassimilates for fruit production seems to be a priority (Bérnad et al., 2009).

The increase in LAl at the highest $\mathrm{N}$ doses and throughout the tomato crop cycle was due to the continuous increase in LA (Figures 1 and 2). A higher LAl increases the interception of solar energy (Heuvelink et al., 2005), which promotes increased production of LDM, SDM and TDM.

The rate of $180 \mathrm{~kg} \mathrm{ha}^{-1} \mathrm{~N}$ provided the highest LAI (2.8), as well as the highest yield (4.3 kg plant $\left.{ }^{-1}\right)$ and fruit yield (143 t $\left.\mathrm{ha}^{-1}\right)$. Therefore, it may be considered suitable for tomato cultivation aiming at industrial processing. Since the optimal LAl threshold is reached, when the plant reaches maximum yield, a higher LAl causes a decrease in yield due to selfshading and excess energy expenditure for respiration, which reduces the carbon balance in the plant (Ardila et al., 2011). In tomato, Hossain et al. (2017) verified a strong correlation of LAI with fruit yield.

The largest increases in LAI was occurred from 56 to 98 DAT, coinciding with the initial flowering and fruiting period. From 98 DAT, with fertilization of 0 and $60 \mathrm{~kg} \mathrm{ha}^{-1} \mathrm{~N}$, the LAl presented a tendency of stabilization, indicating that the plants tend to cease leaf emission. Moreover, leaf loss by senescence exceeded leaf expansion, which was not observed in the fertilization with 120 and $180 \mathrm{~kg} \mathrm{ha}^{-1} \mathrm{~N}$. For doses 0 and $180 \mathrm{~kg} \mathrm{ha}^{-1} \mathrm{~N}$, the LDM/SDM at 98 and 126 DAT was 0.08 and 0.28 , respectively (Table 1 ), indicating greater production and maintenance of leaves. Furthermore, it was verified that the higher the $\mathrm{N}$ rate, the higher the proportion of LDM and LAI.

In summary, $180 \mathrm{~kg} \mathrm{ha}^{-1}$ promoted the best results for FDM (yield) and the values of the indexes and plant characteristics (Table 3) from flowering to 112 DAT. In this period the tomato plant is still well-leafed. This can be used as pattern for new studies for tomato plant for industrial processing.

\section{Materials and methods}

\section{Plant materials}

We used 'Heinz 9553' a tomato hybrid, which is one of the most cultivated genotypes for industrial processing purposes in Brazil and in several regions of the world. The hybrid has been determined with well growth, concentrated maturation. It takes from 110 to 120 days to reach maturity (Soares and Rangel, 2012).

\section{Experimental area}

The experiment was carried out from April to August 2015 in Barretos city, São Paulo State, Brazil, located at 2022'32.37" South latitude, 48039'45.68" West longitude, with an altitude of $507 \mathrm{~m}$. According to the Köppen classification, the climate of the region is type Aw, rainy tropical, with rainfall concentration in the summer and relatively dry winter. A Campbell Scientific ${ }^{\circledR}$ meteorological mini-station was installed at $2 \mathrm{~m}$ height, approximately $300 \mathrm{~m}$ from the experiment site, being set up to perform readings every second and store the average of the data every 30 minutes by means of a datalogger (CR10X, Campbell Scientific, Logan, Utah, USA). During the period of conduction of the experiment, the mean maximum temperature was 25.5 oc $(18.3-32.8 \stackrel{\circ}{ } \mathrm{C})$, and the mean minimum temperature was
$13.5 \stackrel{\circ}{ } \mathrm{C}(6.1-20.9 \stackrel{\circ}{ } \mathrm{C})$. The mean relative air humidity was $58.6 \%$ (17.3 - 100\%).

The soil of the area was classified as Red-Yellow Latosol, according to criteria described in the Brazilian Soil Classification System (Embrapa, 2018).

\section{Treatments and experimental design}

The treatments consisted of $\mathrm{N}$ doses $(0,60,120$ and $180 \mathrm{~kg}$ $\left.\mathrm{ha}^{-1} \mathrm{~N}\right)$ and evaluation times $(14,28,42,56,70,84,98,112$ and 126 days after transplanting - DAT). The experimental design was in randomized blocks, in plots subdivided in time, with three replicates. The experimental units consisted of three plant rows $(9 \times 3.6 \mathrm{~m})$, with spacing of $1.2 \mathrm{~m}$ between rows and $0.25 \mathrm{~m}$ between plants. The data collection area corresponded to the central row, disregarding $0.5 \mathrm{~m}$ from each end.

The source used for the $\mathrm{N}$ supply was urea $(45 \% \mathrm{~N})$. At planting, $60 \mathrm{~kg} \mathrm{ha}^{-1} \mathrm{~N}$ was applied, except for the zero dose treatment. The remaining amounts of $\mathrm{N}$, from each treatment were applied in cover in four times and in equal quantities, at 14, 28, 42 and 56 DAT of 'Heinz 9553' tomato plants. Planting fertilization was performed in the furrow, and cover fertilization in the row, about $15 \mathrm{~cm}$ from the plants; both were performed manually. The incorporation of fertilizers applied in cover was done by central pivot irrigation.

\section{Set up and conduction of the experiment}

Prior to the installation of the experiment, the soil in the 0 $20 \mathrm{~cm}$ layer had: $13 \mathrm{~g} \mathrm{dm}^{-3}$ O.M.; $\mathrm{pH}_{(\mathrm{CaCl} 2)} 5.1 ; 1 \mathrm{mmol}_{\mathrm{c}} \mathrm{dm}^{-3}$ Al; $27 \mathrm{mmol}_{\mathrm{c}} \mathrm{dm}^{-3} \mathrm{H}+\mathrm{Al} ; 19.2 \mathrm{mmol} \mathrm{dm}^{-3} \mathrm{SB} ; 46.2 \mathrm{mmol}_{\mathrm{c}}$ $\mathrm{dm}^{-3}$ CEC and $42 \%$ base saturation; $9 \mathrm{mg} \mathrm{dm}^{-3} \mathrm{P}_{(\text {Resin); }} 1.2$ $\mathrm{mmol} \mathrm{dm}{ }^{-3} \mathrm{~K} ; 14 \mathrm{mmol} \mathrm{dm}^{-3} \mathrm{Ca} ; 4 \mathrm{mmol}_{\mathrm{c}} \mathrm{dm}^{-3} \mathrm{Mg} ; 6 \mathrm{mg} \mathrm{dm}{ }^{-3}$ $\mathrm{S} ; 31 \mathrm{mg} \mathrm{dm}{ }^{-3} \mathrm{Fe} ; 0.29 \mathrm{mg} \mathrm{dm}^{-3} \mathrm{~B} ; 0.7 \mathrm{mg} \mathrm{dm}^{-3} \mathrm{Zn} ; 0.9 \mathrm{mg}$ $\mathrm{dm}^{-3} \mathrm{Cu} ; 2.1 \mathrm{mg} \mathrm{dm}^{-3} \mathrm{Mn}$. According to the granulometric analysis, the soil contained 210,50 and $740 \mathrm{~g} \mathrm{~kg}^{-1}$ of clay, silt and sand, respectively (Raij et al., 2001). Soil K content was classified as low, according to (Trani and Raij, 1997). Soil texture was classified as average.

Plowing, harrowing and liming (RPTN $=120 \%, \mathrm{CaO}=45 \%$, and $\mathrm{MgO}=20 \%$ ) were performed 50 days before the transplanting of seedlings, aiming at $80 \%$ base saturation (Trani and Raij, 1997). In addition to $\mathrm{N}$ fertilization, $400 \mathrm{~kg}$ $\mathrm{ha}^{-1} \mathrm{P}_{2} \mathrm{O}_{5}$ (at planting) and $300 \mathrm{~kg} \mathrm{ha}^{-1} \mathrm{~K}_{2} \mathrm{O}$ were also applied, according to the recommendation of (Trani and Raij, 1997), using simple superphosphate and potassium chloride $(60 \%$ $\mathrm{K}_{2} \mathrm{O}$ ) as $\mathrm{P}$ and $\mathrm{K}$ sources, respectively. For potassium fertilization, $100 \mathrm{~kg} \mathrm{ha}^{-1} \mathrm{~K}_{2} \mathrm{O}$ was applied at planting and the rest was applied in cover four times, equal to quantities, at 14, 28, 42 and 56 DAT.

Seedlings of 'Heinz 9553' tomato were transplanted on April 7, 2015, when they had four leaves. Pest, disease and weed control were performed according to the recommendations for the crop (Clemente and Boiteux, 2012). Central pivot irrigation was performed according to the water requirement of the crop.

\section{Evaluated characteristics}

The plants were collected in 14-day intervals, with the first collection performed at 14 DAT and the last performed at 
126 DAT (end of the cycle), totaling nine evaluation periods. The plants were cut in the hypocotyl region, being subsequently washed. Then, the leaves (leaflet and petiole), stem and fruits were separated and placed in a greenhouse forced with air ventilation at $65 \stackrel{\circ}{\mathrm{C}}$ until reaching a constant weight. Regarding fruits, there were five evaluation times from 70 to 126 DAT, with 14-day intervals.

Leaf area (LA) was obtained by passing the leaflets through an electronic area meter, model 3100 LICOR, with the result expressed in $\mathrm{cm}^{2}$ plant ${ }^{-1}$.

Leaf dry mass (LDM) and shoot dry mass (SDM - leaves + stems) were determined on a precision scale with two decimal places, with the result expressed in $\mathrm{g} \mathrm{plant}^{-1}$.

To determine fruit dry mass (FDM), the fruits were washed and placed in a greenhouse with forced air ventilation at 65 oc until constant mass and then weighed in a precision scale with two decimal places. Total dry mass (TDM) was obtained by addition of SDM and FDM, with the result expressed in $\mathrm{g}$ plant $^{-1}$.

The indices were calculated according to (Benincasa 2003):

Relative growth rate: $R G R=\left(\operatorname{InTDM}_{2}-\operatorname{InTDM}_{1}\right) /\left(t_{2}-t_{1}\right)$, where $\mathrm{In}$ is the neperian logarithm of TDM at times 1 and 2, with the result expressed in $\mathrm{g} \mathrm{g}^{-1}$ day $^{-1}$;

Leaf area ratio: $L A R=$ LA/TDM, with the result expressed in $\mathrm{cm}^{2} \mathrm{~g}^{-1}$;

Specific leaf area: SLA = LA/LDM, with the result expressed in $\mathrm{cm}^{2} \mathrm{~g}^{-1}$;

Leaf mass ratio: LMR = LDM/TDM, with the result expressed in $\mathrm{g} \mathrm{g}^{-1}$;

Leaf area index: $L A I=L A$ /area occupied by the plant; Apparent assimilation rate: $A A R=\left[\left(T_{D M}-T_{2} M_{1}\right) /\left(t_{2}-t_{1}\right)\right] x$ $\left[\left(\operatorname{lnL} A_{2}-\ln L A_{1}\right) /\left(L A_{2}-L A_{1}\right)\right]$, with the result expressed in $\mathrm{g} \mathrm{cm}^{-2}$ day $^{-1}$.

\section{Statistical analyses}

Data were submitted to statistical analysis using the Statistical Analysis System (SAS Institute, 2000). For cases of significant $(p<0.05)$ interaction between $N$ doses and evaluation times, multiple polynomial regression (response surface) analysis was performed using RSREG software.

\section{Conclusion}

The increase in nitrogen supply provided an increase in all growth parameters of the tomato crop. With increased nitrogen doses, the leaf area ratio, leaf mass ratio and leaf area index were higher, and the relative growth rate and specific leaf area were lower.

\section{Acknowledgments}

We thank the Coordination of Improvement of Higher Level Personnel (CAPES) for the scholarship granted the first author to carry out the doctorate degree course.

\section{References}

Almanza-Merchán PJ, Arévalo YA, Cely GER, Pinzón EH, Serrano PAC (2016) Fruit growth characterization of the tomato (Solanum lycopersicum L.) hybrid 'Ichiban' grown under cover. Agron Colomb. 34(2): 155-162.

Ardila GR, Fischer G, Balaguera-López HE (2011) Caracterización del crecimiento del fruto y producción de tres híbridos de tomate (Solanum lycopersicum L.) em tiempo fisiológico bajo invernadero. Rev Colomb Cienc Hortic. 5(1): 44-56.

Azofeifa A, Moreira MA (2004) Analisis de crecimiento del chile jalapeño (Capsicum annuum L. cv. Hot), en Alajuela, Costa Rica. Agron Costarric. 28(1): 57-67.

Bénard C, Gautier H, Bourgaud F, Grasselly D, Navez B, CarisVeyrat C, Weiss M, Génard M (2009) Effects of low nitrogen supply on tomato (Solanum lycopersicum) fruit yield and quality with special emphasis on sugars, acids, ascorbate, carotenoids, and phenolic compounds. J Agr Food Chem. 57(10): 4112-4123.

Benicasa MMP (2003) Análise de crescimento de plantas: noções básicas, 2. ed. Jaboticabal: Funep, 41p.

Cecílio Filho AB, Nowaki RHD (2016) Nutrição e adubação da cultura do tomate para indústria. In: Prado, RM, Cecílio Filho, AB (eds) Nutrição e adubação de hortaliças. Jaboticabal: FCAV/CAPES, p. 447-474.

Clemente FMVT, Boiteux LS (2012) Produção de tomate para processamento industrial. Brasília: Embrapa, 344p.

Dartora J, Echer MM, Guimarães VF, Marini D, Pauletti DR (2014) Crescimento e produção da couve-da-Malásia submetida a adubação nitrogenada. Sci Agrar Paran. 13(2): 133-142.

Elia A, Conversa G (2012) Agronomic and physiological responses of a tomato crop to nitrogen input. Eur J Agron. 40:64-74.

Empresa Brasileira de Pesquisa Agropecuária (2018) Sistema brasileiro de classificação de solos, 5 ed. EMBRAPA: Brasília, p. 222-246.

Heuvelink E, Bakker MJ, Elings AR, Kaarsemaker R, Marcelis LFM (2005) Effect of leaf area on tomato yield. Acta Hort. 691:43-50.

Hossain SAAM, Wang L, Chen T, Li Z (2017) Leaf area index assessment for tomato and cucumber growing period under different water treatments. Plant Soil Environ. 63(10): 461-467.

Kanter DR, Zhang X, Mauzerall DL (2015) Reducing nitrogen pollution while decreasing farmers' costs and increasing fertilizer industry profits. J Environ Qual. 11(2): 325-335.

Kumar M, Meena ML, Kumar S, Maji S, Kumar D (2013) Effect of nitrogen, phosphorus and potassium fertilizers on the growth, yield and quality of tomato var. Azad T-6. Asian J Hort. 8(2): 616-619.

Lawlor DW (2002) Carbon and nitrogen assimilation in relation ti yield: mechanisms are the key to understanding production systems. J Exp Bot. 53(370): 773-787.

Lucena RRM, Negreiros MZ, Medeiros JF, Batista TMV, Bessa ATM, Lopes WAR (2013) Acúmulo de massa seca e nutrientes pelo tomateiro 'SM-16' cultivado em solo com diferentes coberturas. Hortic Bras. 31(3): 401-409.

Omaña HG, Peña H (2015) Acumulación de materia seca y balance de nutrientes en tomate (Solanum Lycopersicum L.) cultivado en ambiente protegido. Bioagro. 27(2): 111120.

Pietro-Souza W, Bonfim-Silva EM, Schlichting AF, Silva MC (2013) Desenvolvimento inicial de trigo sob doses de nitrogênio em Latossolo Vermelho de Cerrado. R Bras Eng Agr Amb. 17(6): 575-580.

Raij B, Andrade JC, Cantarella H, Quaggio JA (2001) Análise química para avaliação da fertilidade de solos tropicais. Instituto Agronômico: Campinas, 285p.

Rashid A, Rab A, Mohammad H, Ali J, Shahab M, Jamal A, Rehman A, Ali M (2016) Effect of row spacing and nitrogen levels on the growth and yield of tomato under walk-in polythene tunnel condition. Pure Appl Biol. 5(3): 426-438. 
San-Martín-Hernández C, Trejo-Téllez LI, Gómez-Merino FC, Volke-Haller VH, Escalante-Estrada JA, Sánchez-García P, Saucedo-Veloz C (2016) Nitrogen and potassium nutrition differentially affect tomato biomass and growth. Interciencia. 41(1): 60-66.SAS Institute (2000) SAS/STAT User's Guide. version 4.0.2. SAS Institute Inc; Cary NC.

Soares BB, Rangel R (2012) Aspectos industriais da cultura. In: Clemente FMVT, Boiteux LS (eds) Produção de tomate para processamento industrial. Embrapa Hortaliças, 331344.
Tei F, Benincasa P, Guiducci M (2002) Critical nitrogen concentration in processing tomato. Eur J Agron. 18(1): 4555.

Trani PE, Raij B (1997) Hortaliças. In: Raij B, Cantarella H, Quaggio JA, Furlani AMC. Recomendações de adubação e calagem para o Estado de São Paulo, (Boletim Técnico, 100). 2. ed. rev. atual. Instituto Agronômico/Fundação IAC, 157-185.

Wira AB, Jamil ZA, Armizatul SAH (2013) Effect of varying nitrogen levels on plant sap characteristics and growth performance of tomato (Lycopercisum esculentum var. baccarat). J Trop Agr Food Sc. 41(2):183-191. 